\title{
繊維の分散と配向を考慮した鋼繊維補強 コンクリート部材の強度と変形 \\ INFLUENCE OF FIBER ORIENTATION AND DISTRIBUTION ON LOOD-DEFORMATION CHARACTERISTICS OF STEEL FIBER REINFORCED CONCRETE MEMBERS
}

\author{
小林一輔*・睦 好宏 史** \\ By Kazusuke KOBAYASHI and Hiroshi MUTSUYOSHI
}

\section{1.はしがき}

鋼緎維補強コンクリート（SFRC）は，ひびわれ拘束 性能, 引張および曲げ強度, 勒性などが普通コンクリー トに比べて格段に優れているので, 最近では舗装やトン ネルのライニングなどへの試験的な適用例も次第に増加 している. 特に掘削直後に地山が膨張するようなトンネ ルのライニングや地震力によって大きい変形を受けるこ とが予測されるコンクリート構造物では, 曲げ強度やせ ん断強度が高いことの他に変形能が大きいことが要求さ れるが, SFRC はこれらの特性を有しているといえる. しかし，SFRCをこれらの構造物に対して本格的に適用 するためには, さらに検討を要する問題点がいくつか存 在する. この中で特に重要な問題点—これは複合材料 に共通の久点でもあるが——は, SFRC の強度のばらつ きが普通コンクリートに比べて大きくなることである. したがって, SFRC を用いて構造物を設計する場合に は，そのばらつきを考慮する必要があり，このためには ばらつきの実体が把握されなければならない。

一般に, SFRCのように短繊維の混入によって補強さ れた複合材料では, 部材断面に㧍ける繊維の分散と配向 性状が部材の力学的挙動にかなり大きい影響を及ぼす.

このことは, SFRC における繊維の分散および配向性 状と, これに影響を及ぼす諸要因との関係を明確にする ことが，上記のばらつきを解明するらえできわめて重要 であることを示している. また, SFRCを上記のような 構造物に適用するためには, その材料力学的特性として の応力一変形関係を明確に把握しておく必要がある.

本研究は, SFRC における鋼㵶維の分散と配向を考慮

* 正会員 工博 東京大学教授 生産技術研究所

** 正会員 工修 埼玉大学助手 工学部建設工学科
して SFRC 部材を設計するための手法を確立すること を目的として実施したものである. 本研究では，まず SFRC における繊維の分散特性を明らかにした．続いて 繊維の配向の定量化を行い, 配向に影響を及ぼす諸要因 との関係を明らかにした。次に SFRC を用いた構造部 材の基本的な力学的特性を明らかにするために, はじめ に繊維の分散と配向の影響を考慮して引張を受ける SFRC の応力ーひずみ曲線を解析的に求めた. 続いて, このようにして求めた応力ーひずみ曲線を用いて曲げを 受ける SFRC 部材の荷重一変形曲線を解析的に求め, こ れを実験的に求めた曲線と対比した結果, 両者が比較的 よく一致することが確かめられた. すなわち, 曲げを受 ける SFRC 部材を設計するための一方法を示したもの である.

\section{2. 鋼織維補強コンクリートにおける繊維の分 散}

(1) 概 要

図一1 は曲げを受ける SFRC ばりの断面における繊

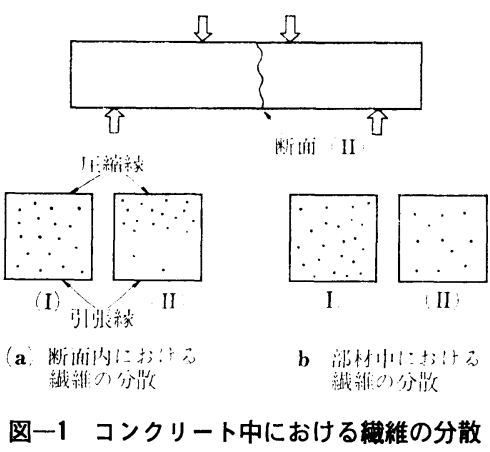


維の分散状態を模式的に示したものである（a）は断面 内の繊維本数は一定であるが断面内における分散状態が 異なる場合を示したものであり（b) は断面内における 纎維の分散状態は一様であるが，断面内の緘維数が異な る場合を示したものである。このように綫維の分散状態 は SFRC の力学的性状に著しい影響を及ぼすことがわ かる.

さてSFRC における繊維の分散状態を取り扱った研究 は以下に述べる山王らによるものを除けば皆無に近い. 山王らは纎維の分散度を評価するために分散係数を提案 し, これを用いて練り混ぜ方法, 締固め方法, 瀻維の形 状寸法および混入率などが纎維の分散度に及ぼす影響を 定量的に評価している1

本章では硬化した SFRC の曲げ供試体における任意 断面および破壊面に打ける纎維本数の分布を調べて, SFRC における鋼繊維の分散特性を明らかにしたもので ある。

\section{（2）実験の概要}

本実験では曲げ強 度試験に用いた数 多くの曲げ供試体 $(10 \times 10 \times 40 \mathrm{~cm})$ に ついて, その破壊面 から離れた任意箇所 から, 供試体軸に直 角に厚さ $10 \mathrm{~mm}$ 程 度の試験片を切り出 した.これらの供試 体に用いたコンクリ ートの配合は鋼繊維 混入率が $1 \%$ のもの と $2 \%$ のものの 2 種

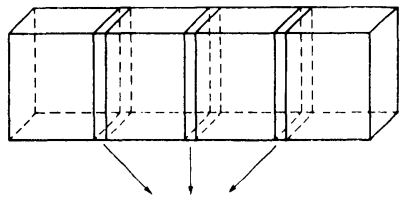

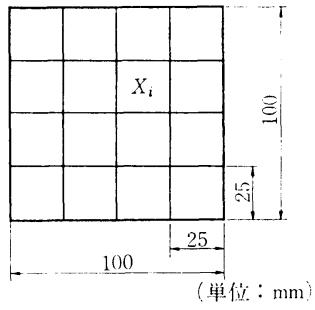

図一2 サンプルの採取位圈 および要素分割
類で, いずれの場合も粗骨材の最大寸法を $10 \mathrm{~mm}$, 水セ メント比を $50 \%$ ，細骨材率を $60 \%$ ，スランプを $10 \mathrm{~cm}$ とした. なお，単位セメント量は前者の場合で $440 \mathrm{~kg} /$ $\mathrm{m}^{3}$, 後者の場合で $490 \mathrm{~kg} / \mathrm{m}^{3}$ である. 鋼繊維はすべて $0.5 \times 0.5 \times 30 \mathrm{~mm}$ のせん断ファイバーを使用した. 次 にこの断面を図一2のように要素に分割して各要素の緎 維本数を測定した. また破壊面も同様に要素に分割し, 両破面の本数を加えることによって, 破壊面における各 要素の繊維本数とした．要素は分割する場合，要素の大 きさは粗骨材の最大寸法 $(10 \mathrm{~mm})$ と有効繊維間隔 (Romualdi はこの值を 0.5 インチとしている) を考慮して 決定した.

\section{（3）コンクリート中における繊維の分散特性}

図一3 は任意断面および破壊面における各要素の繊維 本数の分布を示したヒストグラムの一例である. 任意断 面における繊維の分布は正規分布曲線にほとんど一致し ており, 平均本数も繊維混入率から理論的に求めた值と だいたい同じである。しかし破壊面における繊維分布を 任意断面における繊維分布と比較すると，前者の平均本 数は後者の $2 / 3$ 程度にとどまる.

SFRC の破壊面を観察すると，写真一1 に示すように 普通コンクリートに比べてかなり大きな凹凹がみられ る. 一般にコンクリートのような複合材料の破壊はその 最も弱い欠陥から生ずるが， SFRC では繊維が crack arrester となるために繊維の存在する部分では主たる破 壊は起こらず, 㵶維のない部分に破壊が生じ，それらが 連結して破壊面を形成する．すなわち，SFRC の強度は 実際に混入した瀻維量によって決まるのではなく，それ よりも少ない量によって決まる．図一3 より明らかなよ うに，強度を支配する繊維混入率は実際に混入した平均 混入率から任意断面におけるばらつき量である標潐偏差 に相当する量を差し引いた值にほぼ等しくなる.

図一4 は横軸に繊維混入率, 縦軸に繊維長および䋐維 混入率によるばらつきを考慮した実際にとり得る䋊維量 の範囲を示している. 寸なわち下側の直線が強度を決定 寸る真の繊維混入率となる.

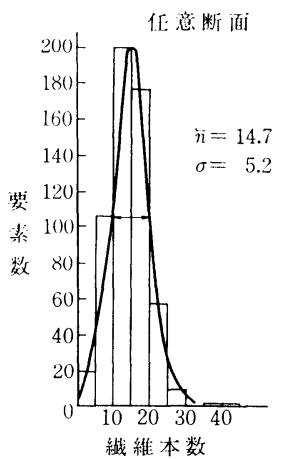

破壊断面j

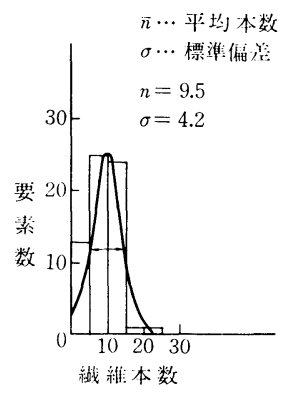

(a) $V_{f}=1 \%$

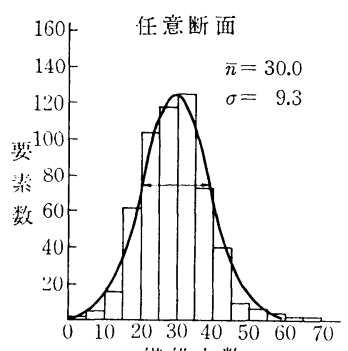

繊維本数

(b) $\quad V_{f}=2 \%$

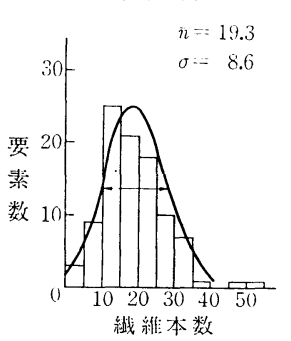

䋐維本数 


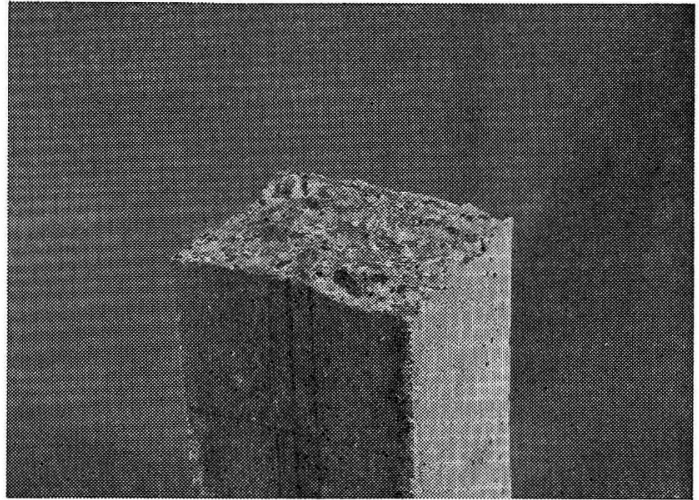

（a）普通コンクリートの破壤面

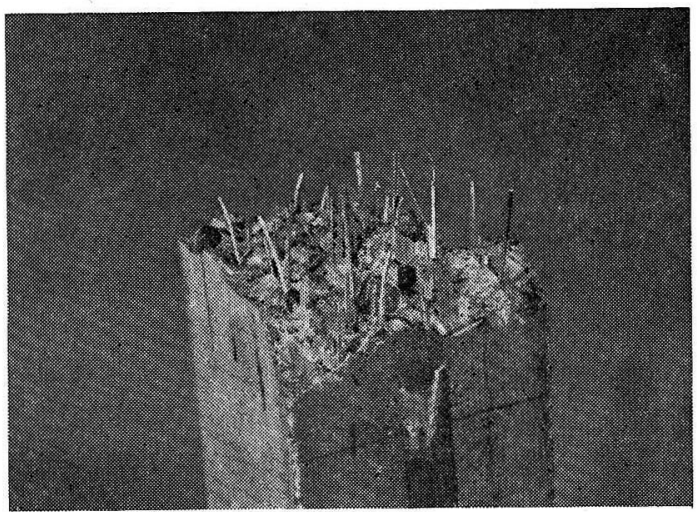

（b）鋼瀻維補強コンクリートの破壤面

写真一1 普通コンクリートと鋼瀻維補強コンクリート の破壊面の比較

\section{3. 鋼繊維補強コンクリートにおける纎維の配 向とその定式化}

\section{(1) 概 要}

SFRC における鋼繊維の配向度は分散度と同様にその 力学的性質に著しい影響を及ぼす．たとえば鋼繊維がす ベて特定の方向に配向している場合とランダム配向して いる場合とでは，1つの方向に作用する引張応力に対し て補強効果はまったく異なってくる゙2. したがって, SFRC を用いた構造部材の設計，またはすでに作られた 部材の強度の推定を行う場合には，鋼繊維の配向度を定 量的に把握しておく必要がある.

コンクリート中における鋼繊維の真の配向度を実験的 に直接求める方法としては, SFRC 試料のX線画像によ る多次元画像情報処理を用いる方法がある ${ }^{1)}$.

本研究でもこの方法を用いて，鋼繊維の配向度とそれ に影響を及ぼす要因との関係を明らかにした，配向度に 影響を及ぼす要因として, 供試体の寸法, 鋼繊維の長さ および型枠の拘束効果による断面内の配向度の分布を取

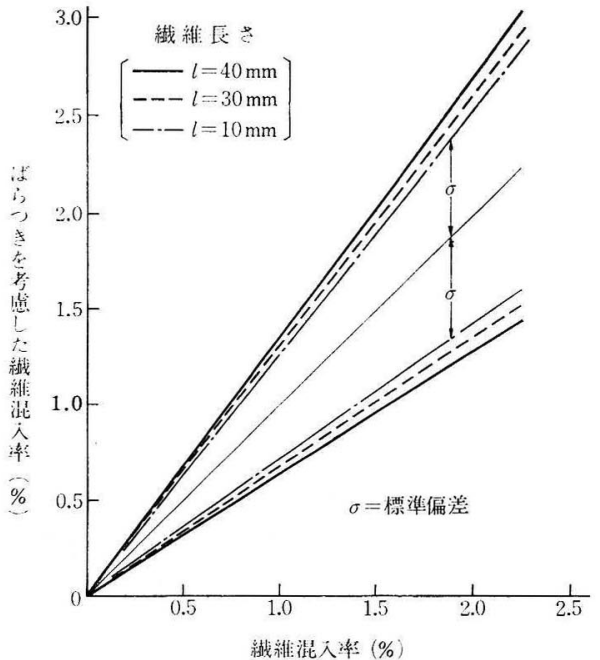

図一4 ばらつきを考慮した緘維混入率

り上げ，SFRC を構造物に適用する場合において繊維の 配向度を定量的に取り扱ら方法を示した.

\section{（2）配向係数の定義および求め方}

配向係数は一軸方向に対する有効率として，ある方向 に繊維を投影したときの長さと，もとの繊維の長さとの 比として定義した.

\section{a) 理論的配向係数}

従来配向係数を求める方法として, 繊維が 3 次元的ラ ンダム配向していると仮定して，0.41 あるいは 0.5 な どの值が理論的 ${ }^{3)}$,4)求められていた。 しかしこれらの 值は繊維が 3 次元 ランダム配向状態である場合に限ら れ，供試体の断面寸法および繊維長などの幾何学的影響 をまったく考慮していない，図一5 に示すように繊維長 $l$, 繊維の中心がとる座標を $(x, y)$ とすると, $x, y<$ $l / 2$ のとき, 繊維は型枠の拘束により幾何学的影響を受 ける.これらを考慮すると, 繊維の位置 $(x, y)$ が決ま るとその繊維が任意にとり得る理論的平均配向係数は $x, y, l$ の関数とな る.たとえば繊維長 $40 \mathrm{~mm}$ の繊維を混 入した SFRC を用 いて $10 \times 10 \mathrm{~cm}$ 断面 の曲げ供試体を作っ た場合，繊維の軸方 向に詨する理論的平 均配向係数 は図一6 に示すように断面内 部においてかなり異 なることがわかる.

この場合の理論的

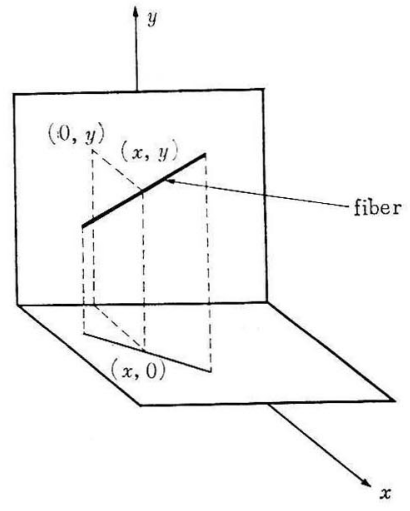

図一5織維の配向と型枠の拘束 


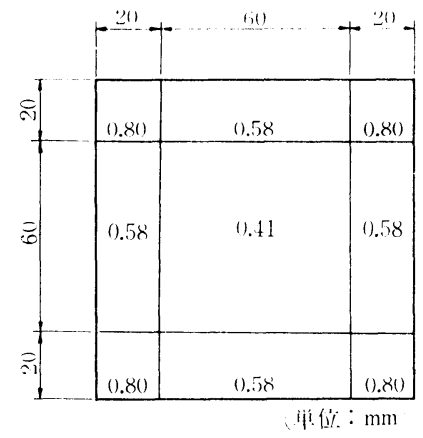

図一6 理論的配向你数の分布（纎維長 : $40 \mathrm{~mm}$ )

平均配向係数は次のようにして求めたものである.すな わち，纎維の中心がとる座標を $(x, y)$ とすると，長さ $l$ の纎維が型枠面によって拘束される条件は，(a) $x<$ $l / 2$ かつ $y<l / 2$, (b) $x<l / 2$ あるいは $y<l / 2$ およ び (c) $x \geqq l / 2$ かつ $y \geqq l / 2$ の 3 つになる. 以上の ち，（a）の場合には繊維は型枠によって 3 次元的に拘束 された配向状態となり，(b) の場合には繊維は型枠によ り 2 次元的に拘束された配向状態となるが，(c) の場合 には繊維はまったく拘束されず， 3 次元ランダム配向状 態となる.これらおのおのの場合の理論的平均配向係数 $\beta$ は次式によって求めることができる.

$$
\beta=\frac{\int_{0}^{\theta} \int_{0}^{\varphi} \cos \theta \cdot \cos \varphi d \theta d \varphi}{\theta \cdot \varphi}
$$

ここに,

$\theta, \varphi:$ 繊維が型枠による拘束条件下で取り得る回 転角でそれぞれ次式で表される。

$$
\theta=f(x, y, l)
$$$$
\varphi=g(x, y, l)
$$

b) $\mathrm{X}$ 線写真から求める方法

SFRC から約 $10 \mathrm{~mm}$ 程度の厚さの試験片を切り出し, その中に含まれる繊維の本数を求め, 試験片の $\mathrm{X}$ 線写 真を撮ると試験片に含まれている全繊維の投影像が求ま る.この像から電子計算機による多次元画像情報処理シ ステムを用いて，試験片に含まれる全繊維の投影面積が 求められ，これから繊維の平均配向係数を求めることが できる．この方法はコンクリート中に存在する繊維の真 の配向度を直接求めることができ，また繊維の分散状態 にかかわらず断面内の配向度の分布を容易に求めること ができる.

\section{（3）実験方法}

a）使用材料，配合および供試体の製作

本実験では骨材として標準砂を用いた. その理由は供 試体断面の寸法を $10 \times 10 \mathrm{~cm}$ から $2 \times 2 \mathrm{~cm}$ まで変化さ せるので, 断面内における綫維の配向度が骨材によって
影響されることを避けるためである．鋼繊維は直径が一 定 $(0.5 \mathrm{~mm})$ でアスペクト比が 40,60 および 80 の 3 種類のカットワイヤーを用いた. 配合は繊維混入率が 1 \% と $2 \%$ の 2 種類とし, いずれの場合も, 水, セメン 卜および砂の重量配合比を $1: 2: 2.9$ とした. 供試体 は断面が $10 \times 10,4 \times 4,2 \times 2 \mathrm{~cm}$ の 3 種類を用いた. 供試体の製作方法は, 試料を 2 層に分けて充填し, 締固 めはいずれの場合も木ゔちによる型枠外部からの打擊の みにより行った。

b）配向係数の測定

(1) 概 要

配向倸数 $\beta$ は図一7に示すように, 繊維は試験片の両 断面を貫くと仮定し，一軸方向に対する有効率 $(\beta=$ $\cos \theta \cdot \cos \varphi)$ として定義した．硬化した供試体から厚さ $5 \pm 1 \mathrm{~mm}$ 程度の試験片を切り出し, 試験片の厚さ $(t)$, 図一8のように分割された各要素の繊維本数 $(n)$ を測定 した. 配向係数は各要素の平均配向係数としてこれを求 めた．配向係数を求めるために，上述した試験片の厚さ $(t)$, 繊維の直径 $(d)$, 各要素中の纎維本数 $(n)$ のほかに 試験片中の繊維の投影長を求める必要があり,このため には繊維の投影面積を測定する必要がある.この測定の ために, 切り出した試験片を軸方向から X 線撮影を行 い, その X 線画像から電子計算機による多次元画像情 報処理を行った。

(2) X 線画像の多次元画像情報処理による配向係数 の決定

$\mathrm{X}$ 線画像における 繊維の投影面積を求めるために用 いた多次元画像画報処理システムについて，その過程を

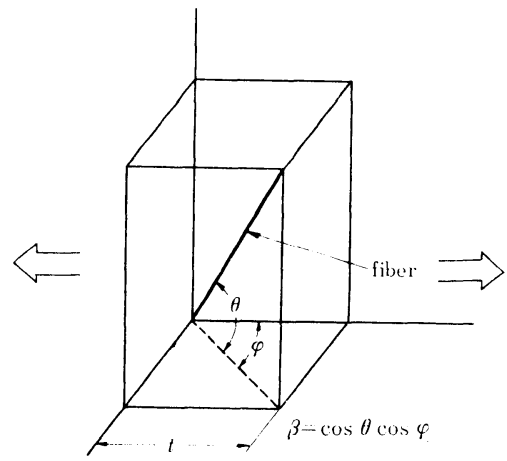

図-1 織維の配向係数

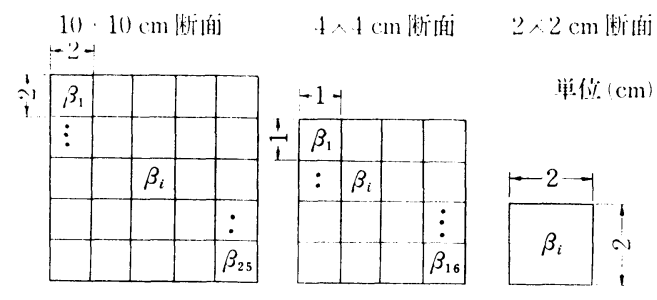

図一8断面寸法と要率分割 
図一9に示す.ま ず，X 線画像を簡 易入力装置にセット して，写真を光源で 照らし，その反射光 を光電管で検出して 画像の読み込みを行 わせ，さらにこれを $\mathrm{A} / \mathrm{D}$ 変換する.画像 の読み込みを行う場 合, $2 \times 2 \mathrm{~cm}$ 要素に

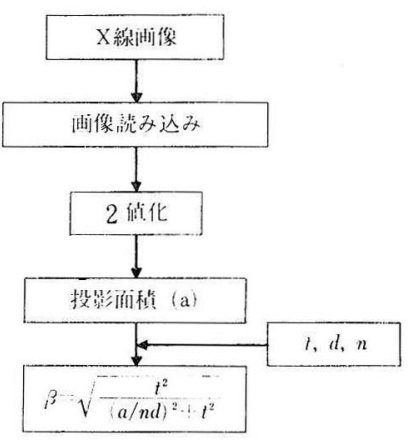

図一9 画像処理過程
ついてはデータサイズで $128 \times 128$, 画素数で 6.4 個/ $\mathrm{mm}, 1 \times 1 \mathrm{~cm}$ 要素ではデータサイズは同じであるが, 画素数で 12.8 個 $/ \mathrm{mm}$ とした. 入力されたデー夕はす べて DISC 内に格納され, 紪維部分と他の部分とに分け るために 2 值化を行う必要がある.ここで 2 值化とは画 像上においてコンクリート部分（黒）と繊維部分（白） に 2 分することを意味する. 2 值化を行う場合，写真に よって濃度レベルがすべて異なり，また繊維部分の重な りなどを考慮して, 実際の䋊維部分の面積を求めること が必要である.このために本実験では 2 值 化した画像を 1 枚 1 枚 X 線写真と比較し て最適な 2 值化レベルを決定した. 2 值化 レベルが決定することによって，各要素の 繊維部分の占める投影面積が求まり, 先に 求めた各要素ごとの纎維本数 $(n)$, 試験片

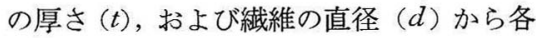
要素の平均配向係数を求めることができ る. 写真一 2 X 線写真㧍よび断面全体 の平均配向係数を示し, 写真一 3 に一要素 を 2 値化した写真を示す.

\section{（4）配向係数に影響を及ぼす諸要因}

図一10 は各断面の各要素に 扝ける配向 係数と供試体断面に㧍ける要素の度数を表 わしたヒストグラムの一例である. 一般に 纎維の長さが短くなると配向係数の分布は 広い範囲にわたって同程度の度数で分布す るが，逆に長くなるとある配向倸数の值に 集中した分布になる傾向がある. この傾向 は断面が小さくなるほど䫓著であって，た とえば $10 \times 10 \mathrm{~cm}$ 断面では配向倸数の值 の上限值と下限值はだいたい同じような值 をとり，ばらつきも同程度であるが， $4 \times 4$ $\mathrm{cm}$ 断面では繊維が短くなるほど配向係数 の上限值と下限值の值は広がり, ばらつき も大きくなる.
$4 \times 4(\mathrm{~cm})$ 断面

$2 \times 2(\mathrm{~cm})$ 断面
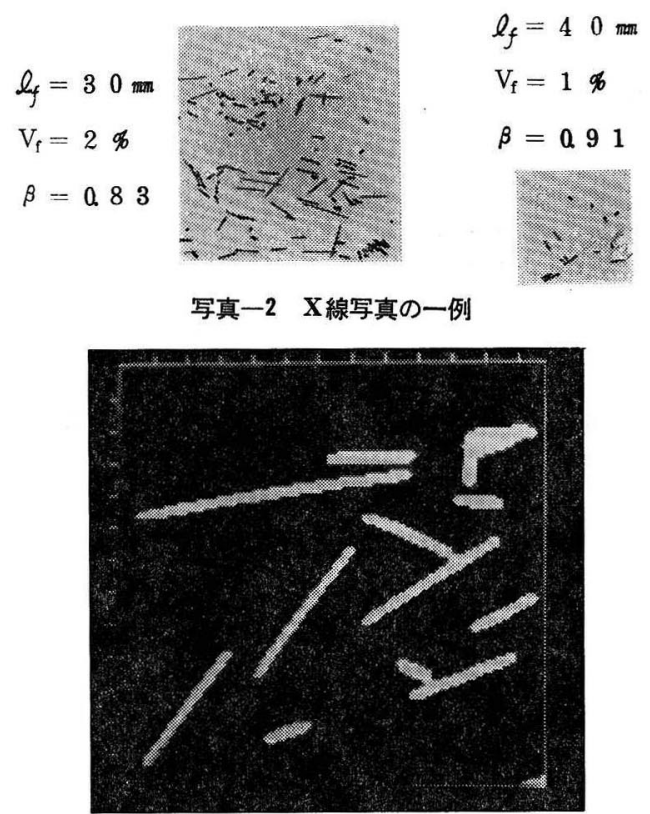

写真-3 2 值化写真
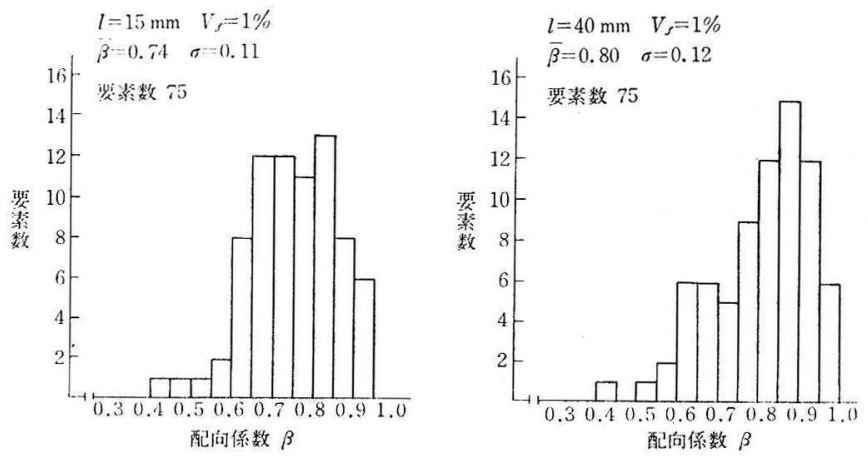

(a) $10 \times 10 \mathrm{~cm}$ 断面

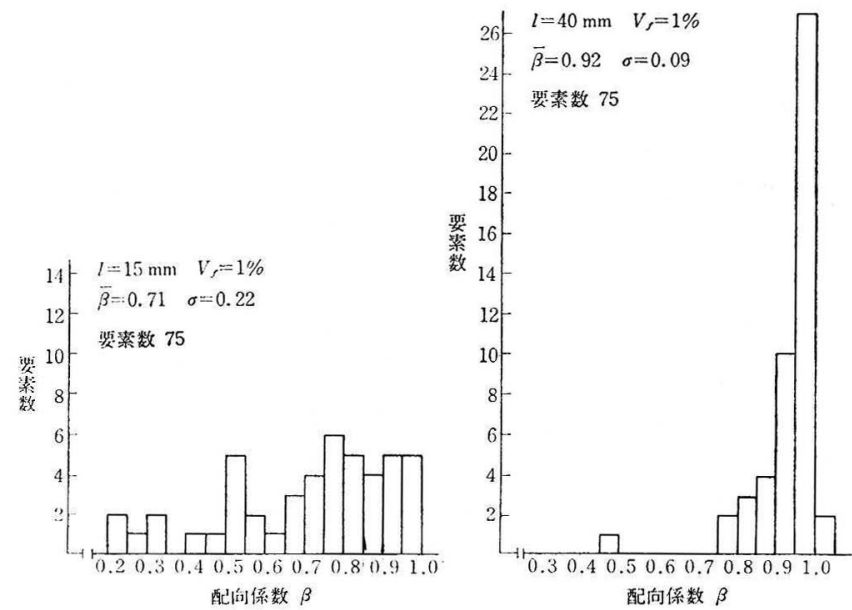

(b) $4 \times 4 \mathrm{~cm}$ 断面

図一10 配向係数の分布 


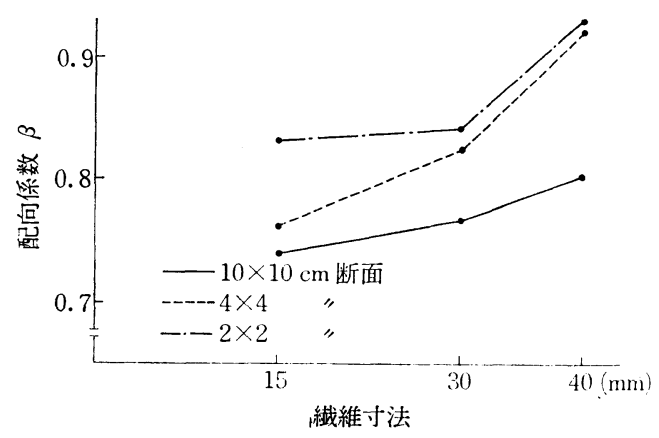

図-11 平均配向你数の実測俌と織維長さとの関係

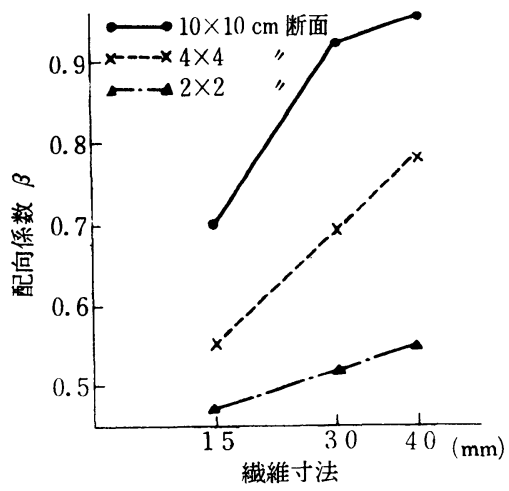

図-12 理論的配向係数と織維長さとの関係

図一11 は各供試体断面の平均配向係数 と断面寸法, および繊維長との関係をそれぞれ示したものである。供 試体の断面寸法が一定のとき，繊維長が長くなるほど， また纎維長が一定のとき，断面寸法が小さくなるほど配 向係数は大きくなる.これは明らかに, 供試体断面の寸 法と緎維による影響がかなり大きいことを示している. 一般に断面寸法が与えられ，纎維の位置が決まるとその 繊維が任意にとり得る理論的平均配向係数は繊維長と供 試体断面の寸法との関数になることはすでに述べたが， これを示したのが 図一12 である.実際に求めた配向倸 数もこれと同じ関係を示している.

次に, 断面内にお

ける配向係数の分布 は，型枠の拘束によ る影響のために断面 内部より断面外部の

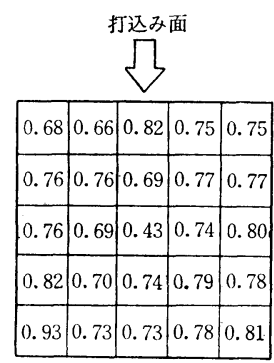

図一13 断面内における配向係数 の分布の一例 值の方が大きくな る.図一13 は断面 内に抢ける配向係数 の分布を画像処理に よって求めた值の一

$l=15 \mathrm{~mm}$ $V_{f}=2.0 \%$

例を示したものである.断面内部では繊維は 3 次元的 ンダムな配向状態をとり得るが，外部では型枠の拘束に より明らかに強制的に配向された状態となる.これを比

\begin{tabular}{|c|c|c|c|c|}
\hline \multirow{2}{*}{\multicolumn{2}{|c|}{$V_{J}=1.0 \%$}} & \multicolumn{3}{|r|}{$(\mathrm{mm})$} \\
\hline & & $l=15$ & $l=30$ & $l=40$ \\
\hline 内 & 部 & 0.72 & 0.72 & 0.83 \\
\hline 外 & 部 & 0.76 & 0.78 & 0.82 \\
\hline \multirow{2}{*}{\multicolumn{2}{|c|}{$V_{f}=2.0 \%$}} & & & $(\mathrm{~mm})$ \\
\hline & & $l=15$ & $l=30$ & $l=40$ \\
\hline 内 & 部 & 0.70 & 0.68 & 0.72 \\
\hline 外 & 部 & 0.78 & 0.77 & 0.77 \\
\hline
\end{tabular}

較するために, $10 \times 10 \mathrm{~cm}$ 断面の内部の要素と外部の要 素の配向係数をそれぞれ平均すると表一1のようにな る. $4 \times 4 \mathrm{~cm}$ 断面では配向係数の分布は $10 \times 10 \mathrm{~cm}$ 断面 と同じ範囲で分布するが，上で述べたように断面内部と 外部における明確な違いはみられなかった。

\section{（5）配向係数の定式化}

以上で述べてきたように, 配向係数に影響を及ぼす要 因の中で，供試体の断面寸法および繊維長による影響が 大きいことが明らかとなった. SFRC を実際の構造物に 適用する場合, 部材断面が比較的大きい場合には繊維は 3 次元ランダムな配向状態であると考えてよいが，小さ い場合，あるいは曲げを受ける部材では緎維の特定方向 への配向による影響が大きいと考えられる.したがって $\mathrm{SFRC}$ 部材の強度, 変形を推定する場合, これらの影響 を加味した設計方法が用いられることが望ましい。

著者らは供試体断 面の影響を考慮した 繊維の断面全体の平 均配向係数を以下の ようにして求めるこ とにした.すなわ ち, 型枠面による繊 維の拘束とその長さ の影響を考慮した平 $l:$ 繊維 $l$

図一14 型枠による拘束域

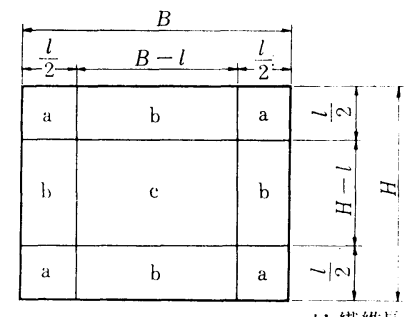
均配向係数に関しては，本章中の（2）「配向係数の定義 および求め方」に示したような方法で，図一14 におけ る $\mathrm{a}, \mathrm{b}$ および $\mathrm{c}$ の領域を決定し，各領域における平均 配向係数 $\beta_{a}, \beta_{b}$ および $\beta_{c}$ を上記の方法による理論值 と実験值の両方から評価してそれぞれ $0.8,0.6$ および 0.4 のごとく求め, これを用いて断面全体の平均配向係 数 $\bar{\beta}$ を以下の式によって求めた.

i ) $B, H \geqq l$ の場合

$$
\bar{\beta}=\frac{K_{1} l^{2}+K_{2} l(B+H-2 l)+K_{3}(H-l)(B-l)}{B H}
$$

ii ) $B \gg H, H>l$ の場合 (平板の場合)

$$
\bar{\beta}=\frac{K_{2} l+K_{3}(H-l)}{H}
$$


ここに,

$$
\begin{aligned}
& K_{1}=\beta_{a}=0.8 \\
& K_{2}=\beta_{b}=0.6 \\
& K_{3}=\beta_{c}=0.4
\end{aligned}
$$

\section{4. 引張を受ける鋼繊維補強コンクリートの忍 カーひずみ関係}

\section{(1) 概 要}

引張荷重下における鋼纎維補強コンクリートの応力ひずみ曲線を, 繊維の分散と配向の影響を考慮して, 解 析的に求める方法を示したものである. この方法は, ま ず引張を受ける断面をある等しい大きさの要素に分割 し, これら各要素について繊維の分散と配向度のパラメ ーターを導入してそれぞれ応力ーひずみ関係を求める. 次に引張荷重下における断面各部の等ひずみを仮定して 各要素の応力を求め, これを平均したものをその断面の 平均応力とすることによって, みかけの応力ーひずみ曲 線を求めるものである.

以上の解析に沶いては次のような仮定を設けている.

(1) 引張断面は平面応力状態にある

(2) ひびわれを生じるまでの引張断面における繊維と マトリックスのひずみは等しい.

（2）繊維の分散と配向の影響を考慮した SFRC の 応力ーひずみ挙動の解析

繊維の分散度と配向度は, 次式で与えられるような平 均繊維間隔 $S_{E}$ によって統一的に表現することができる ので, 各要素における纎維の分散度と配向度の影響はこ の $S_{E}$ によって導入することにした.

$$
S_{E}=\sqrt{\frac{a^{2}}{n}} / \beta
$$

ここに,

\section{$a:$ 要素の一辺の長さ \\ $n:$ 各要素の繊維本数 \\ $\beta:$ 各要素の繊維の配向係数}

この平均繊維間隔 $S_{E}$ は, 一般に䋊維量を $p$, 䋊維の 直径を $d$, 繊維の 3 次元ランダム配向状態のときの配向 係数を $\beta^{\prime}$ としたときに, $S=5 \sqrt{\frac{\pi}{\beta^{\prime}}} \cdot \frac{1}{p}$ によって求め られる断面全体の平均纎維間隔とは次の点で異なる.す なわち，ここでは破壊断面内の一要素における繊維本数 の実測值 $n$ に基づいて，まず全纎維が断面に直角方向に 配向しているとしたときの平均繊維間隔をまったく幾何 学的に $S=\sqrt{\frac{a^{2}}{n}}$ として求め, これに対して繊維の配向 度が複合体の強度および変形に及ぼす影響を考慮した一 種の有効係数として型枠の拘束による影響等を考慮した
各要素の配向係数 $\beta$ を導入し, $S_{E}=S / \beta$ をもって $\mathrm{SFRC}$ 部材の設計に用いる平均䋊維間隔としたものである.し たがって，S によって与えられる平均緘維間隔は, 繊維 補強コンクリートの補強効果に関する平均的なめやすを 与えるが， $S_{E}$ は断面内における局所的な補強効果を表 すために導入した設計上のパラメーターといえる.

各要素の応力ーひずみ関係は次のようにして求めた.

(1) 各要素の応力-ひずみ関係を, 降伏するまでと, 降伏に達してから後の 2 つに分けて考光, bi-linear と 仮定した.

(2) SFRC が粒子強化系複合材料と類似の強化機構を 有すると仮定して, 著者の 1 人が提案した引張強度推定 式を各要素に適用して, 要素ごとに引張強度 $\sigma_{t}$ を求 めた ${ }^{5), 6)}$.

$$
\sigma_{t}=C_{1}\left(\frac{1}{\sqrt{S_{E}}}-\frac{1}{\sqrt{S_{C}}}\right)+\sigma_{m}
$$

ここに,

$\sigma_{t}:$ 一要素における $\mathrm{SFRC}$ の引張強度 $\left(\mathrm{kg} / \mathrm{cm}^{2}\right)$ $S_{E}$ : 一要素に掞ける平均緎維間隔 $(\mathrm{cm})$ で, 前述 のように, $S_{E}=\sqrt{\overline{a^{2} / n} / \beta}$ として表される $S_{C}$ : 鋼繊維が補強効果を生ずる $S$ の上限值, こ こでは 2.7 となる

$\sigma_{m}:$ マトリックスコンクリートの引張強度 $(\mathrm{kg} /$ $\mathrm{cm}^{2}$ )

$C_{1}$ : おもに鋼韯維とコンクリートの付着強度によ ってきまる定数，ここでは 50 とした

(3) SFRC の降伏ひずみに関してはこれを定量的に取 り扱った研究はみあたらないので，ここでは SFRCの 変形能に関しても強度と同様な関係が成立すると仮定し て，その降伏ひずみを次式のように表した。

$$
\varepsilon_{u}=C_{2}\left(\frac{1}{\sqrt{S_{E}}}-\frac{1}{\sqrt{S_{C}}}\right)+\varepsilon_{m}
$$

ここに,

$\varepsilon_{u}:$ 一要素における $\mathrm{SFRC}$ の引張降伏ひずみ $S_{E}, S_{C}$ : 強度推定式で用いたものと同様である

$\varepsilon_{m}:$ マトリックスコンクリートの引張降伏ひず み

$C_{2}:$ 定数, ここでは 150 とした

(4) 各要素の応力-ひずみ挙動は降伏ひずみに達する 前と, 達した後の 2 つの場合に分けて考え, 降伏ひずみ に達した後の挙動に関しては, (1) 各要素の平均繊維間 隔から求められる負の勾配に従って，ひずみの増加とと もに応力は減少する. (2) 強度 $\left(\sigma_{t}\right)$ に対する減少した応 力 $\left(\sigma^{\prime}\right)$ の比 $\left(\sigma^{\prime} / \sigma_{t}\right)$ と䋊維の付着力 $(\pi d l \cdot n \tau / 4)$ の積 が，この応力に加わるという 2 つの仮定を設けた.

前者の仮定は, SFRC のひびわれ強度や引張強度が平 均纎維間隔の平方根の逆数に比例することが一般的に確 
かめられているので, これを下降域にまで拉張したもの であり，一方後者の仮定は次のような根拠に基づいたも のである. すなわち, 降伏ひずみ $\left(\varepsilon_{u}\right)$ に達した後, マ トリックスは部分的にひびわれを生じているので，応力 は負の勾配に従ってひずみの増加とともに減少するが， このときひびわれが生じた量を強度 $\left(\sigma_{t}\right)$ に対する減少 した応力 $\left(\sigma^{\prime}\right)$ に相当する量 $\left(\sigma^{\prime} / \sigma_{t}\right)$ と仮定し,これに緎 維の付着力 $(\pi d l n \tau / 4)$ を乗じたものが下降域に打ける応 力の一部に加えられるものとしたのである.このことは マトリックスにひびわれが生じた部分の耐力を繊維とマ トリックスとの付着力によって置き換えたことになる.

換言すればこの領域では各要素の耐力は複合体として一 体化している部分の耐力と繊維とマトリックス間の付着 カの一部に依存していることになる.

図一15 はこれまでに論じてきた一要素の応力ーひずみ 関係を示したもので，あるひずみが与えられた場合の応 力度は以下のようにして求めることができる。

$\varepsilon<\varepsilon_{u}$ の場合

$$
\sigma=\frac{\sigma_{t}}{\varepsilon_{u}} \cdot \varepsilon
$$

$\varepsilon \geqq \varepsilon_{u}$ の場合

$$
\begin{aligned}
& \sigma=\frac{C_{3}}{\sqrt{S_{E}}} \times\left(\varepsilon_{u}-\varepsilon\right)+\sigma_{t}+\frac{\pi d l}{4} \tau n \times \frac{\sigma^{\prime}}{\sigma_{t}} \\
& \sigma^{\prime}=\frac{C_{3}}{\sqrt{S_{E}}}\left(\varepsilon_{u}-\varepsilon\right)
\end{aligned}
$$

ここに,

$\sigma_{i}, \varepsilon:$ 一要素における $\mathrm{SFRC}$ の引張応力およびひ ずみ

$\sigma, \varepsilon_{u}:$ 一要素における $\mathrm{SFRC}$ の引張強度および降 伏ひずみ

$S_{E}:$ 一要素における平均繊維間隔

$d, l:$ 鋼繊維の直径および長さ

注 1） $\tau$ の值をここでは次のようにして推定した. すなわ ち, 直接引張試験を行うとクロスヘッドの変位と荷重 との関係は 図一16のようになるＡ～点でコンクリー 卜は破壊し, 耐力は $\mathrm{B}$ 点まで下がる. B 点ではひび われは断面全体を貫通し, 繊維の付着力のみによって 荷重を受けもっている状態となる. そのときの荷重を 全繊維が受けもつ付着力とした．この場合，繊維はラ ンダム配向状態にあると考えられるので，ひびわれ面 を横切っている繊維はそれぞれ引張力の作用方向に対 してある傾きを有しており，必ずしも引張応力方向に 配向しているとは限らない, しかし, 既往の研究は繊 維の傾きが付着強度に及ぼす影響はほとんどないこと を示しているので),ここではこの影響を考慮しないこ

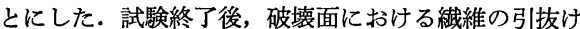
長さを測定し, 以下の式によって付着強度を求めた。

$$
\tau=\frac{P}{\pi d L}
$$

$P:$ 鋼絨維の引抜け時に扝ける荷重

$d:$ 鋼繊維の直径

$L:$ 引抜けた鋼繊維の全長

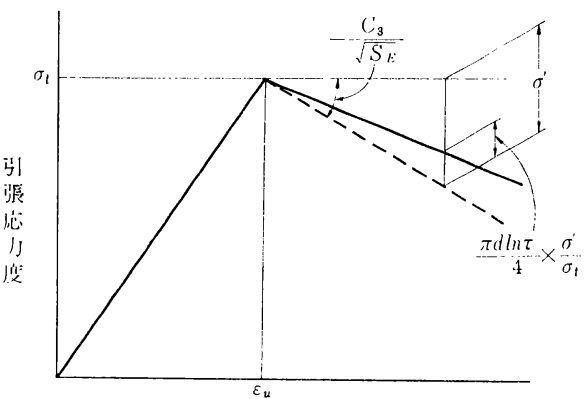

引㜊しず 及

図一15 一要案における応力ーひずみ関係

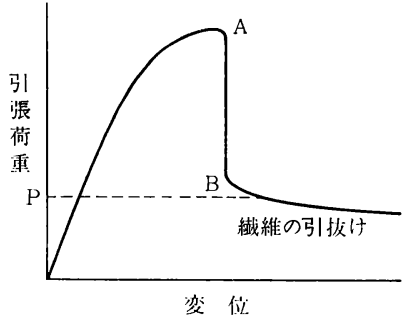

図一16 引張を受ける SFRC の荷重-変位関係のモデル

$\tau:$ 鋼繊維の付着強度 $\left(\mathrm{kg} / \mathrm{cm}^{2}\right)$ ，ここでは 69 $\mathrm{kg} / \mathrm{cm}^{2}$ 注1)とした

$n:$ 一要素における繊維の本数

$C_{3}$ : 定数, ここでは $10^{-2}$ とした

(5) 以上により, 纎維の分散および配向の影響を考慮 した各要素の応力ーひずみ関係が求められたことになる. 次に引張荷重の作用下に扝ける断面の等ひずみの仮定 より各要素の応力が求まり，これを平均したものをその 断面の平均応力とすることによって，系全体のみかけの 応力ーひずみ曲線が計算によって求をることになる.

\section{（3）引張りを受ける鋼緎維補強 コンクリートの応 カーひずみ曲線}

図一17 は，普通コンクリートおよび SFRC の応力ーひ ずみ曲線を図一18 に示すような供試体を用い，直接引 張試験によって実験的に求めた一例を示したものであ る.この場合, 鋼繊維は $0.5 \times 0.5 \times 30 \mathrm{~mm}$ のせん断フ アイバーを用い, 配合は粗骨材の最大寸法が $7 \mathrm{~mm}$ で 表一2 に示寸配合のプレーンコンクリートおよび SFRC を用いた。

図一19 は繊維の分散と配向 を考慮して解析的に求め た応力ーひずみ曲線を示したものである.この場合，平 均繊維間隔 $S_{E}$ を計算するために必要な各要素の繊維本 数 $n$ は, 破断面を $4 \times 4=16$ 個の要素に分割して求め, また各要素の配向保数 $\beta$ は 3. で求めた理論值を用いた. なお,この図では配向係数の分布が等しいが繊維本数の 分布が異なる (A) および (B) の 2 つの断面（図一20 


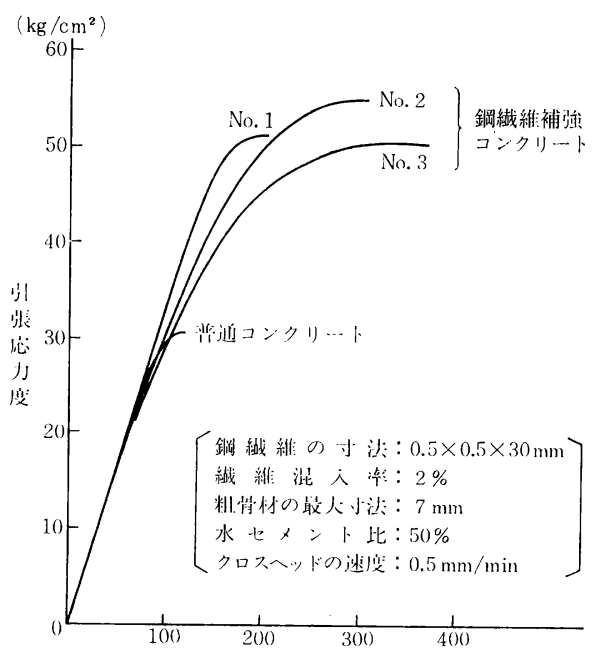

吅版ひずみ $\left(\times 10^{6}\right)$

図一17 実験的に求めた SFRC の引張応力ーひずみ曲線
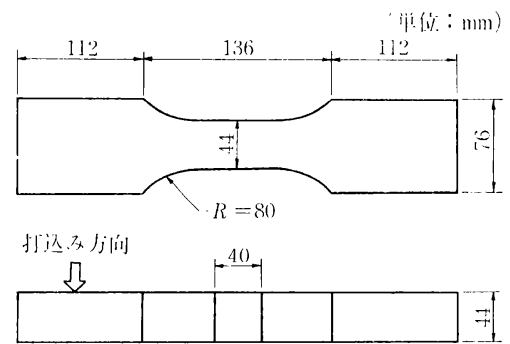

図-18 直接引張試験用供試体の形状寸法

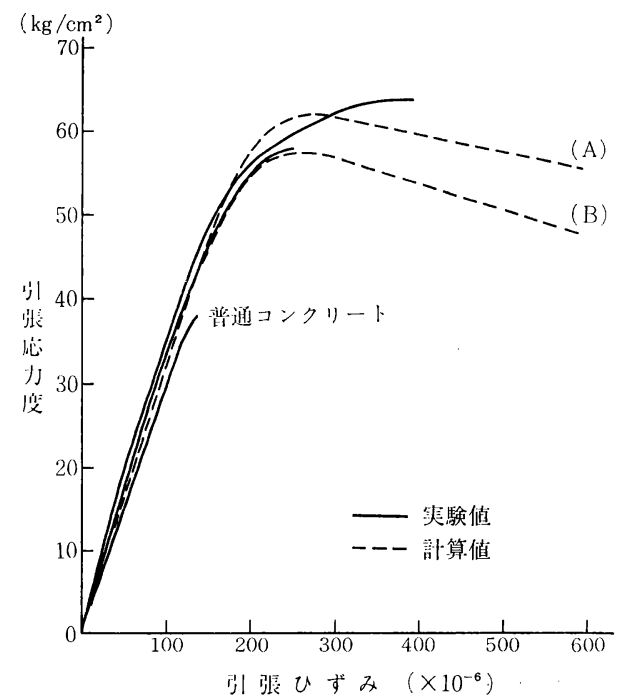

図一19 解析的に求めた SFRC の引張応力-ひずみ曲線

参照）に基づいて求めた曲線を示した.

実験では最大荷重に達してからの挙動は試験機の構造 などにより正確に求めることは難しいが，計算では最大

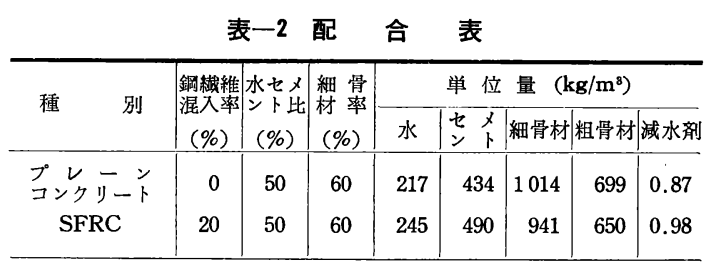

注）粗骨材の最大寸法は, 引張試験には $7 \mathrm{~mm}$, 曲げおよび圧縮試験 には $10 \mathrm{~mm}$ の骨材を用いた。スランプはすべての配合を通じて $10 \sim 13 \mathrm{~cm}$ とした.

(断 脯 A)

\begin{tabular}{|c|c|c|c|}
\hline 1 & 4 & 8 & 10 \\
\hline 3 & 2 & 1 & 2 \\
\hline 1 & 4 & 5 & 5 \\
\hline 5 & 5 & 6 & 2 \\
\hline
\end{tabular}

䋐緗朴数

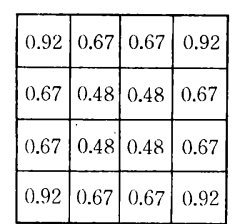

院们係数
(䉼皅; B)

\begin{tabular}{|l|l|l|l|}
\hline 5 & 2 & 6 & 4 \\
\hline 3 & 3 & 2 & 5 \\
\hline 1 & 2 & 1 & 2 \\
\hline 1 & 1 & 1 & 6 \\
\hline
\end{tabular}

繊剂体数

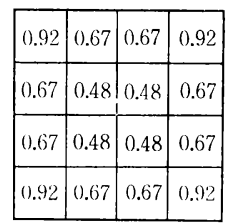

唒们係数

\section{図一20計算に用いた緎維本数および配向係数}

荷重に達してからの下降域の応力ーひずみ挙動が求めら れた。

\section{5.曲げを受ける鋼繊維補強コンクート部材の 荷重と変形}

\section{(1) 概 要}

曲げを受ける鋼繊維補強コンクリート部材の 荷重-変 形関係を解析的に求める方法を示したものであって, 繊 維の分散と配向の影響を考慮した解析を行うことによ り,ばらつきの大きいといわれていた SFRC 部材の荷 重一変形挙動を比較的よい精度で求め得ることを確めた.

この方法はまず曲げを受ける断面をある等しい大きさ の要素に分割し,これら各要素における応力-ひずみ関 係を求めた.この場合, 引張域における応力一ひずみ関係 は 4. で述べた手法を適用して求め, 圧縮応力ーひずみ曲 線は繊維の分散および配向のいかんにかかわらず断面内 で一様であるとみなして求めた．次に断面を水平に $n$ 等 分要素 (discrete element) に分割し，圧縮縁ひずみを 与えて中立軸の計算を行い，これを繰り返すことによっ て荷重一変形曲線が求められる。 なお，本章ではこの方 法をチェックするための曲げ試験も行った. 
以上の解析では断面における平面保持を仮定した. す なわち, 繊維とマトリックスは一体となって, 変形する と考えたまた，鉄筋の応力ーひずみ関係は弾塑性とし， ヤング率を $2.1 \times 10^{6} \mathrm{~kg} / \mathrm{cm}^{2}$ ，降伏ひずみを $2200 \times 10^{-6}$ とした.

\section{（2）曲げを受ける鋼繊維補強コンクリート部材の解 析}

a) 解析の手順

要素分割法 (discrete element method) によって以下 の手順に従い, 解析的に SFRC の荷重一变形曲線を求め た.

すなわち，図一21に 示すように断面を 24 個 の要素に分割し, 各要素 において，実験に用いた 供試体の破壊面から得ら れる繊維本数 $\left(n_{i}\right)$ およ び 3. で求められる理論 的配向係数 $\left(\beta_{i}\right)$ を適用 した.

さらに, これを水平に $n$ 等分要素 (discrete elements) に分割した (図一 22).

次に圧縮縁にある大き

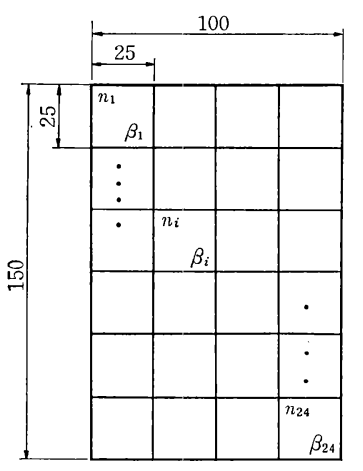

$n_{i}:$ 㵶維本数 $\beta_{i}:$ 配向係数
図一21 曲げ供試体の要素分割 さのひずみを与え，断面内に中立軸の位置を仮定する と, 平面保持の仮定から各要素のひずみが求まる. 引張 域の応力ーひずみ関係は各要素ごとに䋊維の分散 と配向 を考慮して先に求められているので, 各要素の応力を計 算することができる. 次に各要素に生じる応力を合計し 内力のつり合、条件を満足しているかどらかチェックし て満足するまで中立軸の位置を修正しつつ計算を行う． これを，圧縮縁のひずみを段階的に増加させつつ繰り返 し計算を行うことによって, 荷重-変形曲線が求められ る. 以上の解析過程を 図一23 に示す.

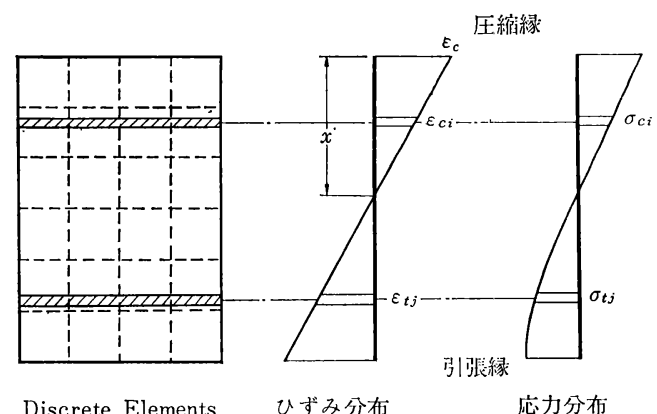

図一22 要素分割 法

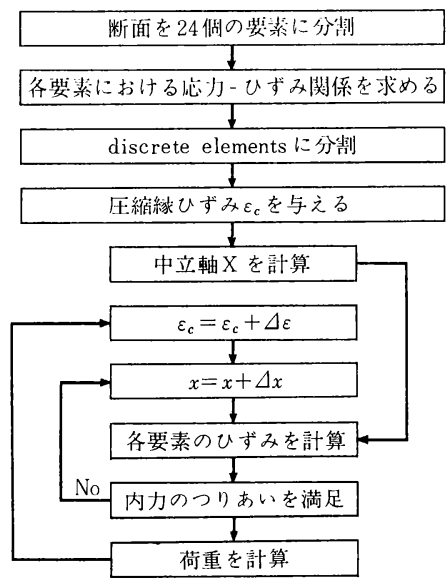

図一23 曲げ解析の過程

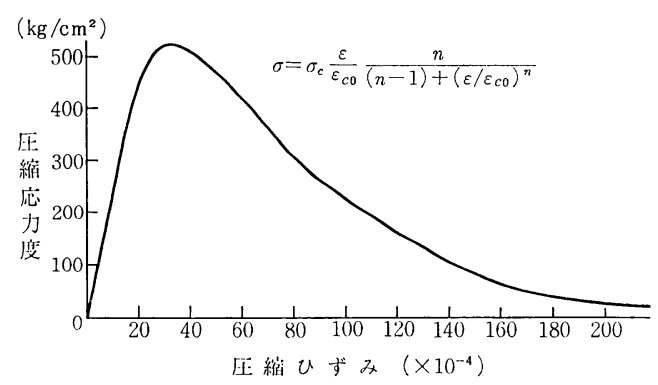

図一24 圧縮を受ける SFRC の応力-ひずみ関係

b） 圧縮域の応力ーひずみ関係について

まず SFRC（鋼繊維 : $0.5 \times 0.5 \times 30 \mathrm{~mm}, V_{f}=2.0 \%$, 配合は表一3 に示す) の圧縮載荷試験によって圧縮応 力ーひずみ曲線を求めたが，各供試体におけるばらつき がほとんど認められなかったので，圧縮域における応力 一ひずみ 関係は繊維の分散と配向の影響を受けず，系全 体で一様であると仮定した. 図一24 は実験的に求めた SFRC の応力-ひずみ曲線の一例である. 本文ではこの ような曲線を以下のように関数表示して，圧縮域の応力 ーひずみ関係を求めた。

$$
\sigma=\sigma_{c} \cdot \frac{\varepsilon}{\varepsilon_{c 0}} \cdot \frac{n}{(n-1)+\left(\varepsilon / \varepsilon_{c 0}\right)^{n}}
$$

ここに,

$$
\begin{aligned}
\sigma_{c} & : \mathrm{SFRC} \text { の圧縮強度 }\left(\mathrm{kg} / \mathrm{cm}^{2}\right) \\
\varepsilon_{c 0} & : \mathrm{SFRC} \text { の降伏ひずみ }\left(\times 10^{-6}\right) \\
n & : \text { 定数, ここでは } 2.5 \text { とした }
\end{aligned}
$$

\section{（3）曲げを受ける鋼繊維補強コンクリート部材の荷 重-変形挙動}

上記の解析方法の適用性をチェックするために，図一 25 に示すような形状寸法のはりを製作した。この図よ り明らかなように，はりは鉄笳を配置したものと SFRC 

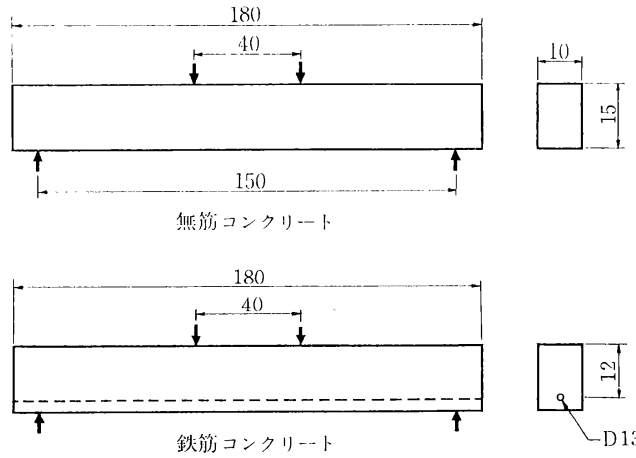

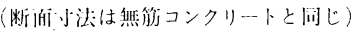

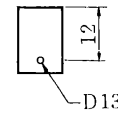

(帮你: $\mathrm{cm}$ )

図一25 曲げ供試体の形状寸法

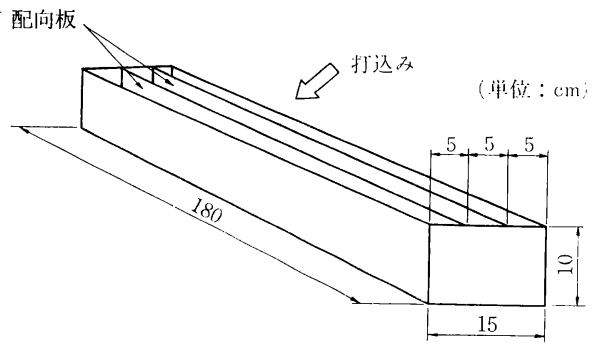

図一26織維を強制配向させるための装置

表一3 曲げ試験結果

\begin{tabular}{|c|c|c|c|}
\hline \multicolumn{2}{|l|}{ 別 } & $\begin{array}{c}\text { ひびわれ荷重 } \\
(\mathrm{kg}) \\
\end{array}$ & $\begin{array}{c}\text { 終 局 耐 力 } \\
(\mathrm{kg})\end{array}$ \\
\hline \multirow{2}{*}{\multicolumn{2}{|c|}{$\begin{array}{l}\text { 普通コンクリートを用いた鉄筋配置ばり } \\
\text { SFRC を用いた鉄筋配置 ばり }\end{array}$}} & 250 & 2100 \\
\hline & & 600 & 2850 \\
\hline \multirow{2}{*}{ SFRC ばり（ランダム配向） } & No. 1 & 400 & 840 \\
\hline & No. 2 & 400 & 900 \\
\hline \multirow{2}{*}{ SFRC ばり（強 制 配 向） } & No. 1 & 400 & 1000 \\
\hline & No. 2 & 500 & 1040 \\
\hline
\end{tabular}

のみのものの 2 種類とした. 鉄笳を配置したものは, さ らに普通コンクリートを用いたものとSFRC を用いたも のがあり, SFRC のみのものは，そのままコンクリート を打設して製作したもの（本文ではランダム配向供試体 とよぶ）と，次に述べるような方法で緘維を強制配向さ せたものがある. 強制配向は 図一26 亿示すような方法, すなわち, 型枠にあらかじめ配向板を $50 \mathrm{~mm}$ 間隔でセ ットしておき, コンクリートを打込んだ後, これを取り 除いて一体とする方法によって行った.

鉄筋は異形鉄筋 D 13 を 1 本配置したので鉄筋比は, $0.8 \%$ となる．また，配合は 表一2 と同様で粗骨材の最 大寸法 $10 \mathrm{~mm}$ のものを用い, 鋼繊維は, 寸法が $0.5 \times$ $0.5 \times 30 \mathrm{~mm}$ のせん断ファイバーを使用した. 載荷試験 は 図一25に示すように, スパン $150 \mathrm{~cm}$, 載荷点間隔 40 $\mathrm{cm}$ の 2 点曲げ載荷により行った.

表一3 注初期ひびわれ荷重および終局耐力の結果を示 したものである.この結果は, SFRC を用いた鉄筋配置

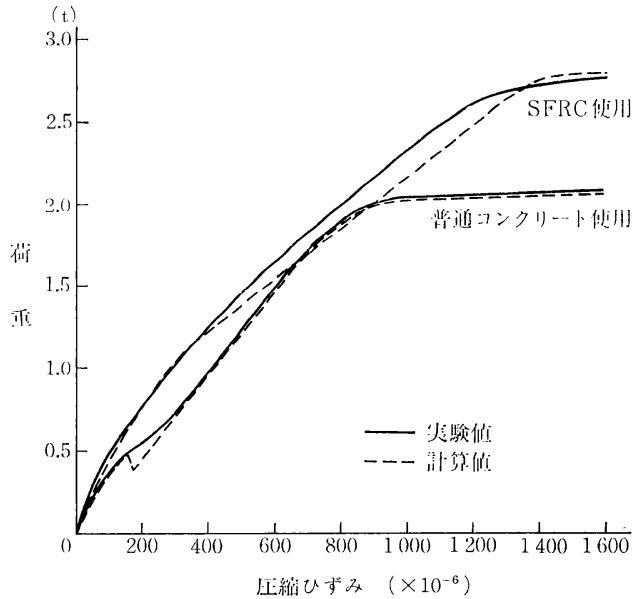

図一27鉄筋配置ばりの曲げ荷重-変形曲線

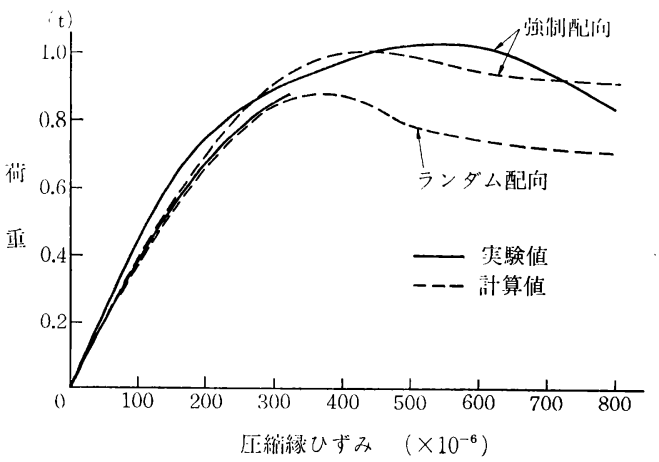

図一28 SFRC ばりの曲げ-荷重変形曲線

〈ランダム配向の場合〉

圧縮縁

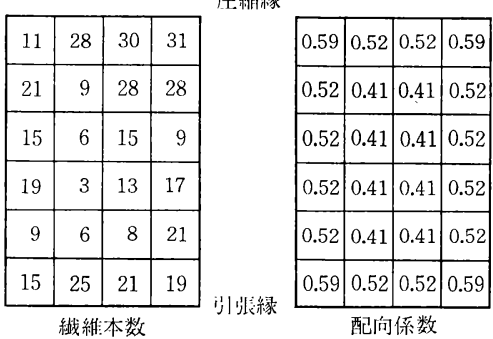

〈放制配们の場合〉

\begin{tabular}{|l|l|l|l|}
\hline 49 & 44 & 49 & 23 \\
\hline 21 & 45 & 20 & 15 \\
\hline 27 & 31 & 15 & 29 \\
\hline 23 & 18 & 19 & 13 \\
\hline 11 & 22 & 17 & 15 \\
\hline 38 & 15 & 15 & 11 \\
\hline
\end{tabular}

䋐維:本数
在維緑

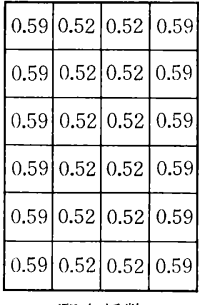

配们係数 
ばりが，普通コンクリートを用いた鉄筋配置ばりに比べ て初期ひびわれ荷重, 終局耐力のいずれも顕著に増大し ていることを示しており，また鉄筋を配置していないは りでは繊維を強制配向させたものの終局耐力がランダム 配向の場合よりも大きいことを示している.

以上の実験によって得られた荷重一変形曲線と, 破壊 面における繊維の分散と配向の影響を考慮して解折的に 求めた荷重一変形曲線を比較して示したものが図一27お よび図一28である.この場合, 計算に用いた断面の繊 維本数㧍よび配向係数を 図一29 に示す。

図一27 および 図一28 は計算によって求めた荷重一変 形曲線が実験值とよく一致しており，このような手法が SFRC 部材の強度と変形を求めるらえで有効であること を示している.

\section{6. まとめ}

本研究は, 鋼繊維補強コンクリートを用いて構造物の 設計を行ら場合に, 避けて通ることのできない緎維の分 散と配向の問題を取り上げ，これを考慮して部材を設計 するための一方法を示したものである. 本研究によって 得られた結論を取りまとめると以下のようになる.

（1）鋼繊維補強コンクリートの強度は, 実際に混入 した繊維量よりも少ない紪維量によって支配される.す なわち, 実際に混入した䋊維量から, 瀻維分布における ばらつき量である標準偏差に相当する量を差引いた量 が, 強度を支配する繊維量となる.

（2）鋼繊維補強 コンクリートにおける繊維の配向 は, 基本的には供試体の断面寸法および繊維長さによっ て支配される。

同一断面内においても断面中央部と型枠に近い部分で は繊維の配向状態が異なる.

（3）曲げを受ける鋼繊維補強コンクリート部材の荷 重-変形挙動は, 引張側の㵶維の配向 の影響を顕著に受 ける.

（4）鋼䋊維補強コンクリート部材の強度と変形は,
部材中における繊維の局所的な分散と配向の影響を考慮 することによって精度よく把握することが可能であるこ とを確かめ, 鋼繊維補強コンクリートを用いた構造部材 を設計するらえでの一手法を示した。

\section{7. あ どき}

本論文は著者の 1 人が東京大学大学院に在学中に修士 論文として取りまとめたものである.

最後に本研究を実施するにあたり, 実験にご協力をい ただいた（株）サンゴの方々，また画像処理を行うにあ たって多大のご指導, ご協力を賜った東京大学生産技術 研究所高木研究室の方々に深謝します.

また材料試験機に関して同研究所の田村研究室のご厄 介になった. ここに記して感謝の意を表します.

\section{参考文 献}

1）山王博之・小林一輔・富田 強：鋼䋊維補強コンクリー 卜の引張強度に及ぼす絨維の分散と配向の影響, 生産研 究, $28,7,1976$.

2）小林一輔, 和泉意登志・趙 力采 : 鋼䋊維補強コンクリ 一ト一一般的性質・強化機構・纎維の配向と分散一, コン クリート工学, 15, 3, 1977.

3) Romualdi, J.P. and J.A. Mandel : Tensile Strength of Concrete Affected by Uniformly Distributed and Closely Spaced Short Length of Wire Reinfercement. ACI Journal, Proc. Vol. 61, No. 6, 1964.

4) Parimi, S.R. and J.K.S. Rao : Effectiveness of Random Fibers in Fiber-Reinforced Concrete, Proc. of the Int. Conf. on Mechanical Behavior of Materials, JSME, pp. 176 186, 1972.

5）小林一輔・趙 力采：短い鋼綫維によるコンクリートの 強化機構生産研究, Vol. 28, No. 7, 1976.

6）小林一輔・趙 力采 : 単軸引張を受ける 鋼繊維補強コン クリートの強度と変形, 土木学会論文報告集, No. 257, 1977.

7) Naaman, A.E. and S.P. Shah : Bond Studies on Oriented and Aligned Steel Fibers, Proc. of the RILEM Symposium 1975 : Fiber Reinforced Cement and Concrete, pp. 171 178, The Construction Press Ltd, 1975.

(1979.2.21 • 受付) 